\title{
2010 Bunsen-Kirchhoff Award for Analytical Spectroscopy
}

\author{
DASp Deutscher Arbeitskreis für angewandte Spektroskopie
}

(C) Springer-Verlag 2009

The German Working group for Applied Spectroscopy (DASp) regularly awards the "Bunsen-Kirchhoff-Preis für analytische Spektroskopie" to honour the work of preferably young scientists from universities, research institutes or industry who have made excellent contributions to analytical spectroscopy. Especially preferred is an oeuvre in new areas like spectroscopy in nano compartments, spectroscopy of biomolecules, etc.

DASp is now seeking nominations for the 2010 BunsenKirchhoff Award for Analytical Spectroscopy. The winner of the Award will receive a certificate and $€ 2.500$ sponsored by Perkin Elmer GmbH. The Award will be presented at the ANALYTICA meeting to be held in March 2010 in Munich (Germany).

Nominations can be made by members of DASp but any scientist meeting the requirements is eligible. Selfnomination is excluded. The winner will be decided by a jury consisting of the current members of the board of DASp.

Further information is available at: http://www.dasp.info

A nomination should include:

1. A letter describing the candidate's accomplishments

2. A list of publications or recent work

3. A scientific curriculum vitae stating the age of the candidate; as well as the candidate's address, phone fax and e-mail.

All documents should be sent not later than 31 December 2009 to:

Prof. Dr. Detlef Günther,

President of the Jury for the Bunsen-Kirchhoff Award 2010, Laboratorium für Anorganische Chemie, ETH Hönggerberg, HCI, CH-8093 Zürich (Schweiz)

(detlef.guenther@inorg.chem.ethz.ch) 